\title{
Isolasi dan Identifikasi Metabolit Sekunder dari Ekstrak Etil Asetat Batang Nangka (Artocarpus heterophyllus Lmk.) dan Aktivitasnya Sebagai Antibakteri
}

\author{
[Isolation and Identification of Secondary Metabolite from Ethyl Acetate \\ Extract of Jackfruit Stem (Artocarpus heterophyllus Lmk.) and Its Antibacterial \\ Activity]
}

\author{
Indriani ${ }^{1 \star}$ dan Iswan ${ }^{1}$ \\ 1) Jurusan Kimia, Fakultas MIPA, Universitas Tadulako, Jl. Soekarno Hatta Km.9, Kampus Bumi Tadulako Tondo Palu \\ *)Coresponding author: indri.2707@gmail.com
}

\begin{abstract}
Isolation and identification of secondary metabolite of ethyl acetate extract of jackfruit stem (Artocarpus heterophyllus Lmk.) as well as its activity as antibacterial have been carried out. The purpose of this study was to know the characterization and antibacterial activity of secondary metabolites from ethyl acetate extract of the Jackfruit stem. Ethyl acetate extract was fractionated and purified using several chromatographic techniques. The identification of the isolated compound was elucidated by spectroscopic UV-Vis, IR, and NMR. Based on data analysis of UV, IR, and NMR spectra showed that the isolated compound was a flavonoid derivative. Antibacterial activity test of the isolated compound to Escherichia coli and Staphylococcus aureus was done by a well diffusion method. The inhibitory zone values of flavonoid compound in concentration series of $1000 \mu \mathrm{g} / \mathrm{ml}, 3000 \mu \mathrm{g} / \mathrm{ml}$, and $5000 \mu \mathrm{g} / \mathrm{ml}$ against E. coli were $9.65 \mathrm{~mm}, 10.25 \mathrm{~mm}$, and $11.00 \mathrm{~mm}$, respectively. While, the inhibitory zone values in the same concentration series against $S$. aureus were $9.00 \mathrm{~mm}, 10.75 \mathrm{~mm}$, and $11.38 \mathrm{~mm}$.
\end{abstract}

Keywords: Jackfruit, Artocarpus heterophyllus Lmk., flavonoid, antibacterial activity.

ABSTRAK. Telah dilakukan isolasi dan identifikasi metabolit sekunder dari ekstrak etil asetat batang nangka (Artocarpus heterophyllus Lmk.).serta aktivitasnya sebagai antibakteri. Tujuan penelitian ini adalah mengetahui karakteristik dan aktivitas antibakteri metabolit sekunder ekstrak etil asetat batang nangka. Ekstrak etil asetat batang nangka difraksinasi dan dimurnikan menggunakan berbagai teknik kromatografi. Identifikasi senyawa isolasi dilakukan dengan teknik spektroskopi UV-Vis, FTIR, dan NMR. Berdasarkan analisis data spektrum UV, IR dan NMR senyawa isolasi adalah turunan flavonoid. Uji antibakteri senyawa isolasi terhadap bakteri Escherecia coli dan Staphylococcus aureus dilakukan mengunakan metode sumur difusi. Nilai zona hambat senyawa turunan flavonoid pada seri konsentrasi $1000 \mu \mathrm{g} / \mathrm{ml}, 3000 \mu \mathrm{g} / \mathrm{ml}$, dan $5000 \mu \mathrm{g} / \mathrm{ml}$ terhadap bakteri $E$. coli yakni $9,65 \mathrm{~mm}, 10,25 \mathrm{~mm}$, dan $11,00 \mathrm{~mm}$, secara berturut-turut. Sedangkan zona hambat pada seri konsentasi yang sama terhadap $S$. aureus yakni $9,00 \mathrm{~mm}, 10,75 \mathrm{~mm}$, dan 11,38 mm.

Kata Kunci : Nangka, Artocarpus heterophyllus Lmk., flavonoid, aktivitas antibakteri.

Riwayat artikel: Diterima 3 April 2020, Disetujui 15 April 2020

Cara sitasi: Indriani., \& Iswan. (2020). Isolasi dan Identifikasi Metabolit Sekunder dari Ekstrak Etil Asetat Batang Nangka (Artocarpus heterophyllus Lmk.) dan Aktivitasnya Sebagai Antibakteri. KOVALEN: Jurnal Riset Kimia, 6(1): 81-89.

DOI: https://doi.org/10.22487/kovalen.2020.v6.i1.15047 


\section{LATAR BELAKANG}

Artocarpus merupakan genus utama dari famili Moraceae yang terdiri dari 50 spesies dan tersebar dari Asia Selatan, Asia Tenggara ke kepulauan Solomon, Kepulauan Pasifik, Australia Utara, dan Amerika Tengah (Kochummen 1987; Verheij \& Coronel, 1992). Sebanyak 23 spesies terdapat di kawasan hutan tropis Indonesia (Heyne, 1987). Beberapa spesies dari genus Artocarpus yang tersebar di Asia Tenggara digunakan sebagai obat tradisional (Perry, 1980; Heyne, 1987), salah satu diantaranya adalah Artocarpus heterophyllus.

A. heterophyllus atau yang dikenal dengan nama lokal nangka telah dimanfaatkan sebagai obat diare, demam, perangsang produksi air susu pada wanita dan hewan, antisifilis, obat cacing, penyembuhan abses, gigitan ular, pembengkakan kelenjar, obat anemia, asma, dermatitis, dan batuk (Balbach and Boarim, 1992). Kemampuan pengobatan oleh $A$. heterophyllus tersebut disebabkan bioaktivitas senyawa metabolit sekunder yang terkandung di dalamnya. Hasil penelitian terdahulu menunjukkan genus Artocarpus mengandung senyawa metabolit sekunder dari golongan flavonoid, terpenoid, neolignan, stilbenoid, dan arilbenzofuran (Hakim, 2010).

Senyawa metabolit sekunder ataupun ekstrak dari $A$. hetephyllus memiliki berbagai bioaktivitas, diantaranya sebagai antioksidan (Ko et al., 1998 ) antiinflamasi (Wei et al., 2005), antineoplasma (Arung et al., 2010), penghambat biosintensis melanin (Arung et al., 2006), antidiabetes (Fernando et al., 1991), antikariogenik (Sato et al.,1996), antifungi dan antibakteri (Khan et al., 2003). Aktivitas antibakteri metabolit sekunder merupakan spektrum yang paling luas dalam pemanfaatan dan pengembangan sebagai bahan baku obat.

Bakteri Escherichia coli dan Staphylococcus aureus merupakan bakteri yang menyebabkan penyakit pada manusia. E. coli dapat menginfeksi saluran kencing (Jawetz et al., 2005), infeksi selaput pada otak (Madappa, 2011), serta menginfeksi usus buntu dan infeksi pada luka pasca operasi (Kayser et al., 2005).

Bakteri lain yang dapat menyebabkan infeksi adalah bakteri Staphylococcus aureus. Jenis penyakit yang ditimbulkan oleh $S$. aureus yaitu adanya bakteri di dalam aliran darah manusia atau istilah medis yaitu bacteremia, penyakit endocarditis yaitu infeksi pada bagian lapisan dalam jantung manusia (Lowy, 1998), infeksi pada paru-paru (pneumonia) (Kollef et al., 2005), serta dapat menyebabkan infeksi supuratif (bernanah) pada manusia ataupun hewan (Quinn, 2002).

Penelitian terdahulu telah mengungkapkan bahwa $A$. heterophyllus memiliki aktivitas antibakteri. Golongan senyawa flavonoid yang terkandung dalam daun $A$. heterophyllus dapat menghambat pertumbuhan $S$. aureus pada konsentrasi 10000 ppm dengan nilai zona hambat 10,50 mm untuk fraksi FA dan 7,25 mm untuk fraksi FH (Darmawati et al., 2015). Konsentrasi 50 $\mathrm{mg} / \mathrm{ml}$ dan $100 \mathrm{mg} / \mathrm{ml}$ ekstrak metanol, etanol, dan kloroform getah buah $A$. heterophyllus mampu menghambat bakteri $E$. coli sebesar14 $\pm 2.82 \mathrm{~mm}$ dan $16.3 \pm 3.55 \mathrm{~mm}$; $10.3 \pm 1.53 \mathrm{~mm}$ dan $14 \pm 2 \mathrm{~mm} ; 13.6 \pm 1.52 \mathrm{~mm}$ dan 15.3 \pm 1.52 , secara berturut-turut (Madhavi et al., 2013). Penelitian yang telah dilakukan Loizzo et al. (2010) menunjukkan bahwa ekstrak etil asetat daun $A$. heterophyllus mampu menghambat $E$. coli dengan nilai MIC 
(Minimum Inhibitor Concentration) 225.6 \pm 4.5 $\mu \mathrm{g} / \mathrm{mL}$ dan diameter zona hambatnya $9.5 \pm 1$ $\mathrm{mm}$, sedangkan nilai MIC untuk $S$. aureus sebesar $221.9 \pm 2.8 \mu \mathrm{g} / \mathrm{mL}$ dan diameter zona hambatnya $12 \pm 1 \mathrm{~mm}$. Secara berturut-turut nilai zona hambat fraksi etil asetat pada kulit batang, empulur batang, kulit akar, empulur akar, buah, daun, dan biji $A$. heterophyllus pada konsentrasi $4 \mathrm{mg} /$ disk terhadap $S$. aureus, yaitu $20 \mathrm{~mm}, 10 \mathrm{~mm}, 16 \mathrm{~mm}, 18 \mathrm{~mm}$, $18 \mathrm{~mm}, 12 \mathrm{~mm}$, dan $16 \mathrm{~mm}$ serta untuk E. coli, yaitu $14 \mathrm{~mm}, 12 \mathrm{~mm}, 16 \mathrm{~mm}, 14 \mathrm{~mm}, 16 \mathrm{~mm}$, $16 \mathrm{~mm}$, dan 18 (Khan et al., 2003).

Sejauh ini uji aktivitas antibakteri terhadap tumbuhan $A$. heterophyllus hanya pada ekstrak kasar ataupun fraksi saja, oleh karena itu untuk lebih mengetahui bioaktivitas metabolit sekunder maka akan dilakukan isolasi dan identifikasi senyawa metabolit sekunder ekstrak etil asetat batang nangka, serta uji aktivitas antibakteri melalui tahapan ekstraksi, fraksinasi, dan pemurnian. Identifikasi senyawa akan dilakukan melalui analisa hasil UV-Vis, FTIR, dan NMR.

\section{METODE PENELITIAN}

\section{Bahan dan Peralatan}

Bahan dasar yang digunakan dalam penelitian ini yaitu batang nangka yang diambil dari Perumahan Untad, Kelurahan Tondo, Kecamatan Mantikulore, Palu, Sulawesi Tengah. Pelarut yang digunakan untuk ekstraksi dan kromatografi berkualitas teknis sedangkan untuk analisis spektrofotometer berkualitas pro-analisis (p.a). Bahan-bahan yang digunakan antara lain metanol, $n$ heksan, akuades, etil asetat (EtOAc), kloroform, kertas saring Whattman, silika gel Merck 60 (70-200 mesh) untuk kromatografi kolom gravitasi dan impregnasi, silika gel
Merck $60 \mathrm{GF}_{254}$ (ukuran silika > 200 mesh) untuk KVC, silika gel Merck (35-70 Mesh) untuk KKG dan plat KLT silika gel Merck kiesegal $60 \mathrm{~F}_{254}$ 0,25 mm untuk KLT. Bahan lain yang umum digunakan sebagai uji aktivitas antibakteri seperti Nutrien Agar, Lactose Broth, bakteri S.aureus, E.coli, DMSO, kloramfenikol, dan alkohol 70\%.

Alat yang digunakan dalam penelitian ini antara lain rotary vacum evaporator, neraca analitik, satu set alat kromatografi vakum cair (KVC), kromatografi kolom gravitasi, lampu UV, kuvet, serta alat-alat gelas yang umun digunakan dalam penelitian kimia organik. Untuk analisis senyawa hasil isolasi digunakan instrumen UV-Vis, FTIR, dan NMR.

\section{Prosedur Penelitian}

\section{Ekstraksi dan isolasi}

Ekstraksi sampel dilakukan dengan maserasi menggunakan pelarut metanol. Serbuk batang nangka sebanyak $4 \mathrm{~kg}$ dimaserasi menggunakan metanol selama $3 \mathrm{x}$ 24 jam. Ekstrak metanol dipekatkan dengan rotary vacum evaporator. Ekstrak metanol pekat dipartisi berturut-turut dengan $n$-heksan dan etilasetat. Ekstrak etilasetat yang diperoleh diuapkan pelarutnya sampai kering. Ekstrak etil asetat sebanyak $40 \mathrm{~g}$ difraksinasi menggunakan kolom kromatografi vakum cair (KVC) dengan eluen (heksan : etil asetat) pada perbandingan $7: 3,6: 4,5: 5,4: 6,3: 7,2: 8$, $1: 9$, dan $100 \%$ etil asetat. Hasil fraksinasi dianalisis dengan Kromatografi Lapis Tipis (KLT). Hasil analisis diperoleh 17 subfraksi yang dibagi menjadi 2 fraksi utama yakni fraksi A $(0.038 \mathrm{~g})$ dan fraksi B $(9.3 \mathrm{~g})$. Fraksi B dilakukan fraksinasi dan diperoleh fraksi $\mathrm{Ba}$ (450 mg) dan Bb (71 mg). Fraksi Ba difraksinasi lebih lanjut menggunakan teknik kromatografi kolom gravitasi dengn campuran 
pelarut. eluen (heksan : aseton) pada perbandingan $9: 1,8: 2,7: 3,6: 4,5: 5$, dan $100 \%$ aseton dan menghasilkan fraksi Ba1 (39 mg), Ba2 (80 mg) dan Ba3 (223 mg). Fraksinasi Ba2 secara berulang diperoleh senyawa dengan noda tunggal, yang selanjutnya diuji dengan dua sistem eluen yang berbeda yakni campuran heksan-etil asetat (7:3) dan campuran heksan : aseton $(7,5: 2,5)$.

Senyawa yang diperoleh dilakukan identifikasi menggunakan spektrofotometer UV, IR, dan NMR.

\section{Pengujian aktivitas antibakteri}

\section{Persiapan bahan uji antibakteri}

Nutrien agar (NA) dilarutkan sebanyak 5 gram dalam $250 \mathrm{ml}$ akuades, kemudian disterilkan ke dalam autoklaf pada suhu $121^{\circ} \mathrm{C}$ dengan tekanan $1 \mathrm{~atm}$ selama 15 menit (Fitrial, 2009).

\section{Pembuatan suspensi bakteri uji}

Satu mata ose bakteri diambil dari biakan agar miring dan diinokulasikan ke dalam media cair steril Lactose Broth, kemudian diinkubasi selama 18-24 jam pada suhu $37^{\circ} \mathrm{C}$.Kultur bakteri siap digunakan untuk pengujian aktivitas antibakteri (Fitrial, 2009).

3. Pengujian aktivitas antibakteri metode difusi sumur

Senyawa hasil isolasi yang berasal dari tumbuhan nangka dilakukan pengujian aktivitas antibakteri menggunaka metode difusi sumur. Sebanyak tiga variasi konsentrasi yaitu $1000 \mu \mathrm{g} / \mathrm{ml}, 3000 \mu \mathrm{g} / \mathrm{ml}$, dan $5000 \mu \mathrm{g} / \mathrm{ml}$, sampel uji dalam pelarut DMSO (Dimetil Sulfoksida). Media NA sebanyak $15 \mathrm{~mL}$, dimasukkan ke dalam cawan petri kemudian dimasukkan bakteri dengan cara dituangkan ke permukaan media dan didiamkan hingga memadat.
Setelah itu, dibuat sumuran dengan diameter $\pm 8 \mathrm{~mm}$ dengan menggunakan alat pelubang media. Sampel senyawa, kontrol positif kloramfenikol dan kontrol negatif DMSO dimasukkan dalam masing-masing lubang dalam cawan petri yaitu sebanyak $50 \mu \mathrm{L}$ dan diinkubasi selama 24 jam pada suhu $37{ }^{\circ} \mathrm{C}$, kemudian diamati untuk melihat zona hambatnya (Normayunita, 2015).

\section{HASIL DAN PEMBAHASAN}

Senyawa isolasi yang diperoleh berupa padatan berwarna kuning pucat sebanyak 13 mg. Hasil uji KLT dengan 2 sistem eluen yang berbeda yaitu (heksan : etil asetat) (7:3) (1) dan (heksan : aseton) (7,5:2,5) (2) memperlihatkan noda tunggal dengan nilai $\mathrm{R} f$ masing-masing adalah 0,5 dan 0,3 (Gambar 1).
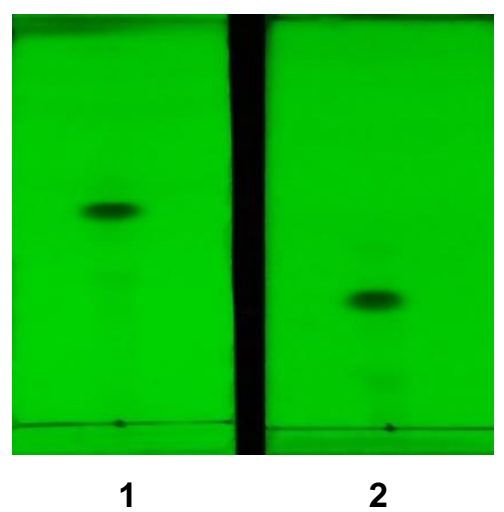

Gambar 1. Kromatogram KLT senyawa hasil isolasi

\section{Senyawa Hasil Isolasi}

\section{Hasil identifikasi senyawa dengan UV-Vis}

Senyawa hasil isolasi diidentifikasi menggunakan UV-Vis, untuk melihat adanya gugus kromofor, yaitu diena terkonjugasi $(\mathrm{C}=\mathrm{C}-\mathrm{C}=\mathrm{C})$ dan enon $(\mathrm{C}=\mathrm{C}-\mathrm{C}=\mathrm{O})$, dengan kisaran sinar dengan panjang gelombang 200$400 \mathrm{~nm}$. Panjang gelombang maksimum merupakan dasar dari analisis kuantitatif 
karena setiap senyawa yang mengandung kromofor dan berwarna memiliki panjang gelombang maksimum yang spesifik (Ibrahim dan Marham, 2013).

Spektrum UV senyawa hasil isolasi dalam pelarut metanol memberikan serapan maksimum pada pita I $\lambda_{\text {maks }}=344 \mathrm{~nm}$ dan pada pita II $\lambda_{\text {maks }}=288 \mathrm{~nm}$ yang menunjukkan adanya transisi dari $\pi \rightarrow \pi^{*}$ dari ikatan rangkap $\mathrm{C}=\mathrm{C}$. Pola spektrum UV-Vis tersebut menunjukkan bahwa senyawa hasil isolasi spesifik untuk pola kromofor senyawa flavon. Pita I menunjukan adanya kromofor sinamoil (340-380 nm), dan pita II menunjukan adanya kromofor benzoil (250-280 nm) (Markham, 1998).

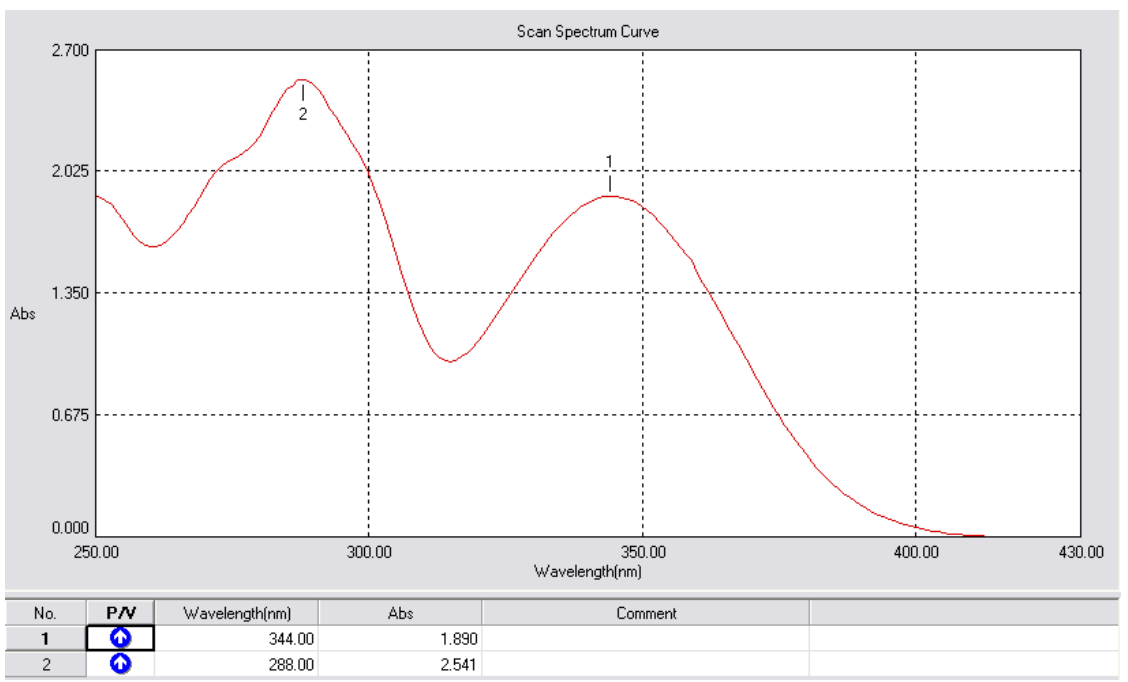

Gambar 2. Spektrum UV senyawa isolat

Hasil identifikasi senyawa dengan spektroskopi Inframerah

Senyawa hasil isolasi menunjukkan beberapa gugus fungsi. Serapan lebar pada $3402,43 \mathrm{~cm}^{-1}$ menunjukkan adanya gugus hidroksil (O-H) (Gambar 3). Alkohol dan fenol memberikan serapan lebar yang terjadi lebih ke kanan pada $3500 \mathrm{~cm}^{-1}$ hingga $3200 \mathrm{~cm}^{-1}$, kadang-kadang saling tumpang tindih dengan serapan rentangan $\mathrm{C}-\mathrm{H}$ (Sastrohamidjojo, 2013).

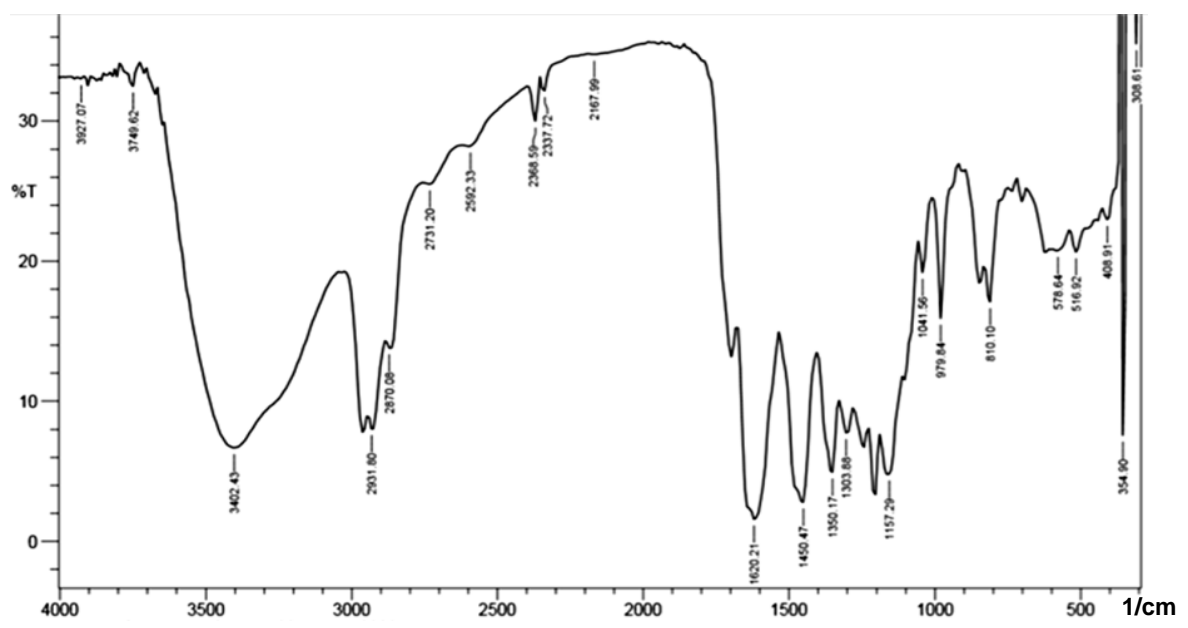

Gambar 3. Spektrum IR senyawa isolat 


$\begin{array}{cl}\text { Hasil identifikasi senyawa dengan } & \text { penguatan hasil analisis IR, agar dapat } \\ \text { spektroskopi NMR } & \text { memastikan golongan dari senyawa hasil } \\ \text { Data }{ }^{13} \mathrm{C} \text { dan }{ }^{1} \mathrm{H} \text { NMR di bawah ini hanya } & \text { isolasi. }\end{array}$
dijelaskan secara parsial sebagai data

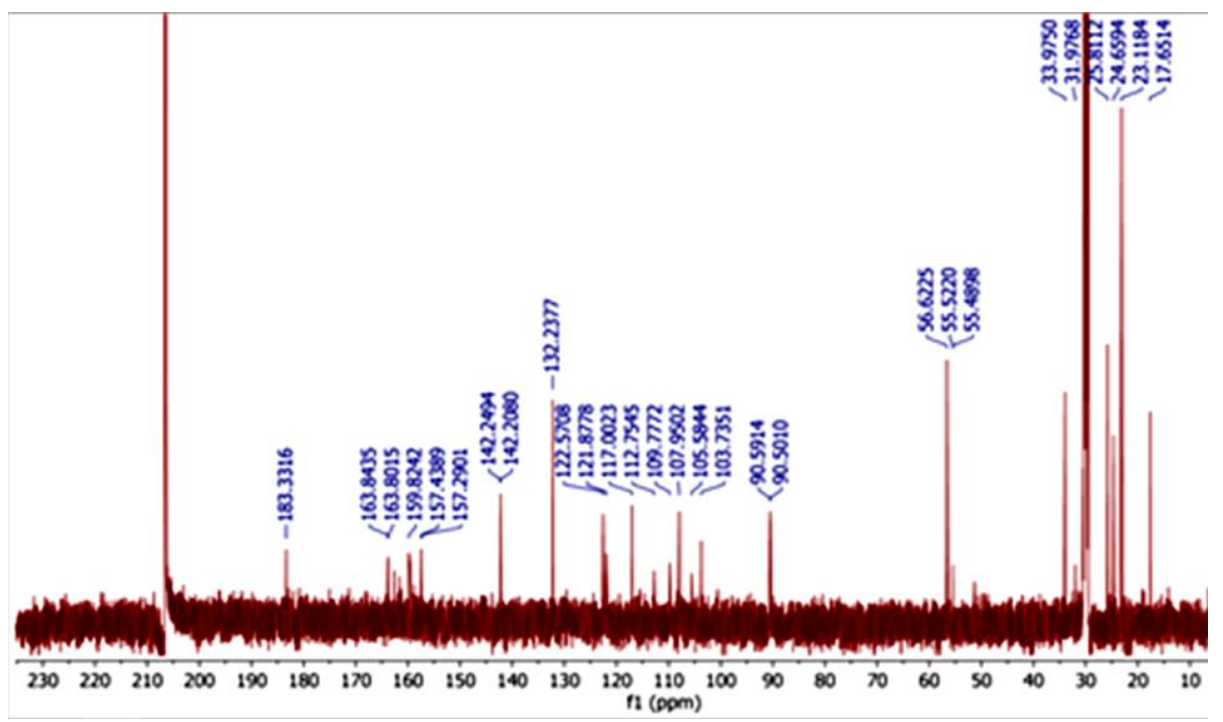

Gambar 4. Spektrum ${ }^{13} \mathrm{C}-\mathrm{NMR}$ senyawa isolat

Spektra menunjukkan kedudukan pergeseran kimia 183,3316 merupakan kedudukan yang khas sebagai serapan karbonil $(C=O)$ (Gambar 4). Hal ini sekaligus menguatkan bahwa serapan $1620,21 \mathrm{~cm}^{-1}$ pada data IR benar menunjukkan keberadaan gugus karbonil.
Spektra ${ }^{1} \mathrm{H}-\mathrm{NMR}$ memperlihatkan adanya sinyal yang berada pada pergeseran kimia $(\delta)$ 6-8 ppm, yang merupakan ciri khas pergeseran untuk senyawa-senyawa aromatik (Gambar 5). Berdasarkan data spektra UVVis, IR, dan NMR isolat batang nangka ( $A$. heterophyllus Lmk) yang diperoleh merupakan senyawa turunan flavonoid.

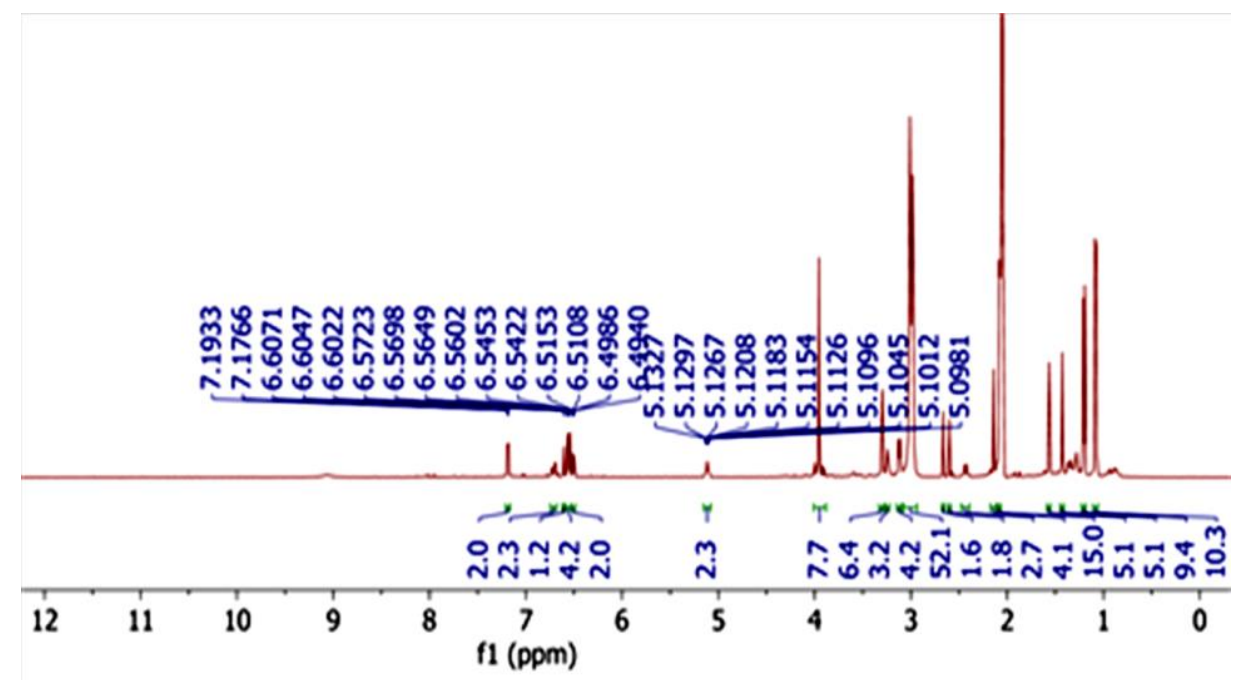

Gambar 5. Spektrum ${ }^{1} \mathrm{H}$-NMR senyawa isolat 
Aktivitas Antibakteri dengan Metode Difusi Sumur

Hasil uji antivitas antibakteri senyawa isolat menunjukkan penghambatan pada semua konsentrasi terhadap $E$. coli dan $S$. aureus, seperti yang terlihat pada tabel 1 . Penghambatan tertinggi terhadap E. coli yaitu pada konsentrasi 5000 ppm dengan nilai zona hambat $11 \mathrm{~mm}$ dan terendah pada konsentrasi
1000 ppm dengan nilai zona hambat 9,65 mm, serta terhadap $S$. aureus penghambatan tertinggi pada konsentrasi 5000 ppm dengan nilai zona hambat $11,38 \mathrm{~mm}$ dan terendah pada konsentrasi $1000 \mathrm{ppm}$ dengan nilai zona hambat $9 \mathrm{~mm}$. Hal ini membuktikan bahwa senyawa turunan flavonoid memiliki aktivitas antibakteri.

Tabel 1. Diameter zona hambat isolat, kontrol negatif dan kontrol positif pada E. coli dan S. aureus.

\begin{tabular}{ccccccc}
\hline \multirow{2}{*}{$\begin{array}{c}\text { Konsentrasi } \\
(\mu \mathrm{g} / \mathrm{ml})\end{array}$} & \multicolumn{3}{c}{ Zona hambat $(E$. coli $)(\mathrm{mm})$} & \multicolumn{3}{c}{ Zona hambat $(S$. aureus $)(\mathrm{mm})$} \\
\cline { 2 - 7 } & $\begin{array}{c}\text { Isolat } \\
(\mathrm{AH} 2)\end{array}$ & $\begin{array}{c}\text { Kontrol } \\
(+)^{*}\end{array}$ & $\begin{array}{c}\text { Kontrol } \\
(-)^{* *}\end{array}$ & $\begin{array}{c}\text { Isolat } \\
(\mathrm{AH} 2)\end{array}$ & $\begin{array}{c}\text { Kontrol } \\
(+)\end{array}$ & $\begin{array}{c}\text { Kontrol } \\
(-)\end{array}$ \\
\hline 1000 & 9,65 & 17,50 & - & 9,00 & 18,5 & - \\
3000 & 10,25 & 24,00 & - & 10,75 & 17,50 & - \\
5000 & 11,00 & 26,00 & - & 11,38 & 24,00 & - \\
\hline
\end{tabular}

${ }^{*}$ Kontrol positif $=$ Kloramfenikol

${ }^{\star *}$ Kontrol negatif $=$ DMSO

Senyawa golongan flavonoid dalam menghambat bakteri setidaknya terdiri atas 3 mekanisme, yaitu menghambat sintesis asam nukleat, menghambat fungsi dari membran sitoplasma, dan menghambat metabolisme energi. Galangin menunjukkan aktivitas antibakteri dengan menyebabkan peningkatan yang nyata dalam kehilangan kalium dari sel $S$. aureus, sebagai indikasi kerusakan langsung pada membran sitoplasma (Cushnie and Lamb, 2005). Kuersetin, apigenin, dan 3,6,7,3`,4'pentahidroksiflavon mampu menghambat $E$. coli dengan cara menyerang aktivitas DNA girase E. coli (Ohemeng et al., 1993).

\section{KESIMPULAN}

Hasil isolasi senyawa metabolit sekunder dari fraksi etil asetat batang nangka (Artocarpus heterophyllus Lmk) adalah senyawa golongan flavonoid. Uji antibakteri menunjukkan bahwa senyawa turunan flavonoid memiliki kamampuan dalam menghambat pertumbuhan bakteri baik pada bakteri Escherichia coli maupun Staphylococcus aureus

\section{UCAPAN TERIMAKASIH}

Secara khusus peneliti menyampaikan ucapan terimakasih kepada Laboran Jurusan Kimia, khususnya Dewi Indriani, S.Si. atas bantuan dan kerjasamanya selama kegiatan penelitian.

\section{DAFTAR PUSTAKA}

Arung, E. T., Wicaksono, B. D., Handoko, Y. A., Kusuma, I. W., Shimizu, K., Yulia, D., \& Sandra, F. (2010). Cytotoxic Effect of Artocarpin on T47D Cells. Journal of Natural Medicine, 64: 423-429. 
Balbach, A., Boarim, D.S.F. (1992). As Frutas na Medicina Natural. Editora Missionaria, Sao Paulo.

Cushnie, T.P.T., and Lamb, A. J. (2005). Detection of Galangin-Induced Cytoplasmic Membrane Damage in Staphylococcus aureus by Measuring Potassium Loss. Journal of Ethnopharmacology, 101(1-3): 243-245.

Darmawati, A.A.S.K., Bawa I.G.A.G. dan Suirta I.W. (2015). Isolasi dan Identifikasi Senyawa Golongan Flavonoid pada Daun Nangka (Artocarpus heterophyllus Lmk) dan aktivitas antibakteri Terhadap Bakteri Staphylococcus aureus. Jurnal Kimia, 9(2): 203-210.

Fernando, M.R., Wickramasinghe, S. M. D. N., Thabrew, M. I., Ariyananda, P. L., and Karunanayake, E. H. (1991). Effect of Artocarpus heterophyllus and Asteracanthus longifolia on Glucose Tolerance in Normal Human Subjects and in Maturity-Onset Diabetic Patients. Journal of Ethnopharmacology, 31(3): 277-282.

Fitrial, Y. 2009. Analisis Potensi Biji dan Umbi Teratai (Nymphaea pubescens Willd) untuk Pangan Fungsional Prebiotik dan Antibakteri Escherichia coli enteropatogenik K 1.1. [Tesis]. Pasca Sarjana Institut Pertanian Bogor, Bogor.

Hakim, Aliefman. (2010). Diversity of Secondary Metabolites from Genus Artocarpus (Moraceae). Nusantara Bioscience, 2(3): 146-156.

Heyne K. (1987). Useful Plants of Indonesia II. Penerbit Badan Litbang Kehutanan. Jakarta.

Ibrahim, S. dan Marham, S. (2013). Teknik Laboatorium Kimia Organik. Garaha IImu, Yogyakarta.

Jawetz, E., Melnick, J. L., dan Adelberg, E. A. (2005). Mikrobilogi Kedokteran. Edisi XXII, 327-335, 362-363, Salemba medika, Jakarta.

Kayser, F. H., Bienz, K. A., and Zinkernagel, R.M. (2005). Fungi as human pathogen. Medical Microbiology. Thieme Sttugart, New York.
Khan, M. R., Omoloso, A. D., and Kihara, M. (2003). Antibacterial activity of Artocarpus heterophyllus. Fitoterapia, 74(5): 501505.

Ko, F. N., Cheng, Z. J., Lin, C. N., and Teng, C. M. (1998). Scavenger and antioxidant properties of prenylflavones isolated from Artocarpus heterophyllus. Free Radical Biology and Medicine, 25(2): 160-168.

Kochummen, K. M. (1987). Moracea in tree flora of Malaya. Vol. 2. Forest Research Institute. Kepong, Malaysia.

Kollef M.H., and Micek S.T. (2005). Staphylococcus aureus Pneumonia a "Superbug" Infection in community and hospital settings. CHEST 128: 1093-7.

Lowy, F.D., (1998). Staphylococcus aureus Infections. NEJM.

Madappa, Tarun. (2011). Escherichia coli Infections. (diunduh dari http://emedicine.medscape.com/article/21 7485overview\#showall. Mei 2019).

Markham, K.R. (1988). Cara Mengidentifikasi Flavonoid. Alih Bahasa Kosasih Padmawinata. Institut Teknologi Bandung. Bandung.

Normayunita, S., Anam, dan Khumaidi, A. (2015). Aktivitas antibakteri Fraksi Ekstrak Kulit Buah Mentah Pisang Ambon (Musa paradisiaca auleus). Online Jurnal of Natural Science, 4(3): 300-309.

Ohemeng, K. A., Schwender, C. F., Fu K. P., and Barrett J. F. (1993). DNA gyrase inhibitory and antibacterial activity of some flavones. Bioorg Med Chem Lett 3: 225-230.

Perry, L. M. (1980). Medicinal plants of east and south-east asia attributed properties and uses. MIT-Pres, Cambridge.

Quinn, J.P., Annie, W., Michael, L., Lee, D. (2002). Molecular correlation for the treatment outcomes in bloodstream Infections caused by Escherichia coli and Klebsiella pneumoniae with reduced susceptibility to ceftazidime. Clinical Infectious Diseases. 34(2): 135-146

Sastrohamidjojo, Hardjono. (2013). Dasardasar Spektroskopi. UGM Press, Yogyakarta. 
Sato, M., Fujiwara, S., Tsuchiya, H., Fujii, T., linuma, M., Tosa, H., and Ohkawa, Y. (1996). Flavones with antibacterial activity against cariogenic bacteria. Journal of Ethnopharmacology, 54(2-3): 171-176.

Verheij E. W. M., and Coronel, R. E. (1992). Plant resources of south asia No. 2 edible fruits and nuts. Prosea Foundation. Bogor

Wei, B. L., Weng, J. R., Chiu, P. H., Hung, C. F., Wang, J. P., and Lin, C. N. (2005). Antiinflammatory flavonoids from Artocarpus heterophyllus and Artocarpus communis. Journal of Agricultural and Food Chemistry, 53(10): 3867-3871. 